\title{
Ethical Implication of Genetic Gender Manipulation for Economic Recession
}

\author{
Osebor Ikechukwu Monday ${ }^{1}$ Stephen CC Chukwuma Esq²
}

1. Lecturer: Department of Arts and Humanities Delta State Polytechnic Ogwashi-Uku PmB 1030, Nigeria Email Osebormonday1@gmail.com, Osebordarry@yahoo.com, Orchid: https://orcid.org/0000-0002-2642-662X

2. Senior Lecturer: Department of Arts and Humanities Delta State Polytechnic Ogwashi-Uku PmB 1030, Nigeria

DOI: https://doi.org/10.3329/bioethics.v10i3.50393

\begin{abstract}
A recession is a significant decline in economic activities. The effects of economic recession include general economic decline, drop in the stock market and increase in unemployment. While some have argued that bilateral relationship among nations is an ethical response to problem of economic recession but it does not solve the problem. The paper suggests genetic gender determination. Genetic gender determination is an agent-based ethics. It involves the scientific manipulation of the fetus of a woman to determine the gender of her offspring. Ethical issues linked to genetic gender determination, unbalance sex ratio, manipulation of genome, and possible spread of infectious or communicable diseases. The paper concludes that the genetic gender determination would help to cushion the effects of economic recession.
\end{abstract}

Keywords: Genetic gender determination, infectious and communicable diseases, economic recession and common good.

Introduction: The effects of economic recession include; inflation, bankruptcies, death, the rise in the price of goods and services, abnormal increases in unemployment, falls in the availability of credit, shrinking output and investment, reduction in the amounts of trade and commerce, as well as volatile relative currency value fluctuations. In addition, the effect of economic recession is intimate partner violence. The Intimate partner violence (IPV) is the "behaviors perpetrated by a person's spouse or romantic partner that include physical violence, sexual violence, or psychological/emotional violence, including behavior designed to control a victim's movements, interpersonal contacts, and access to financial resources" ${ }^{\text {. The Intimate }}$ partner violence (IPV) has led to the reproduction of babies, which one may be able to care.

The economic benefits of a policy, legalizing genetic gender determination enable couples to determine their family size and balance the gender of their children. Gender determination might be nevertheless justified, if it addresses adequately the negative side effects of gender imbalance in society-the gender crisis. We maintain that it is morally justified to choose the gender of one's offspring with the end of mitigating the harmful effects of an economic recession. 
However, the blame for a recession generally falls on the federal leadership of a country ${ }^{2}$.Governments do not manage the economic recession, through the approach of genetic gender determination. While some argue that genetic gender determination discourages reproductive autonomy but it discourages unplanned family hood.

Recessions can alter family life by constraining the choices that individuals and couples make concerning their family lives and by activating the family's role as an emergency support system ${ }^{3}$.

Genetic gender determination could lead to the manipulation of human genome for patriarchal reasons. Men centric society portrays memorable inconsistent force relations between woman and men. ${ }^{4}$. Gender determination is "to pick a male child, which in turn perpetuates gender preference ${ }^{5}$. The objection to genetic gender determination is the irrational of a sexist society. In a men centric society, productivity and performance of men is assumed generally to be highly rated, to women ${ }^{6}$. While we support the permissibly of gender selection, men-centric society is unethical, it repudiates human dignity and such a policy might be discriminatory against women.

There are many solutions linked to problem of economic recession, increase bilateral relationship, devaluation of currency, consumption of homegrown food and many others. In this paper, we are concerned with the ethical Implication of genetic gender determination for economic recession. First, let us discuss the background of gender determination.

Background: The instinct to determine the gender of an offspring is as old as man is. In ancient Greece, it's believed that if a man had sex with a woman, raising the right side of his legs, a boy will be conceived. In the eighteenth-century, it is also mythical that if a man ties off his left testicle while having sex with a woman, the woman will conceive a boy ${ }^{7}$. Christina et al. presented mythical views on gender determination; (a) preceding ovulation with an intercourse (b). A water and heating soft drink before intercourse (c) 2 tablespoons of soft drink (d) profound entrance of male at the hour of climax ${ }^{8}$.

A female child will be born if the following steps should be taken [a] Intercourse should stop 2 to 3 days before ovulation. (b)Intercourse before corrosive vaginal douche (c) 2 tablespoons of white vinegar per quart of water (d) No female climax. (d) Shallow entrances by the male at the hour of discharge (e) No restraint until definite intercourse 2 to 3 days before ovulation ${ }^{4}$.

Timing of sexual intercourse is referred as Shettle's method of gender determination. The calculation of women (ovulation) before sex helps to determine the gender of an offspring 5 . Gender of an offspring is dogged by strong and weak sperm cells. "Strong" sperm cell fertilizes an egg, the result is a male child and when "weak" cell sperm cell fertilizes an egg, the offshoot is a female child ${ }^{5}$.

The question is, how can we know the empirical distinctions between weak or strong sperm cells? We contend that the claims of the ancient philosophers on gender determination are myths and probabilities.

Sperm sorting: Sperm sorting is a genetic method of gender determination. Sperm 
sorting is the separation of $\mathrm{X}$ or $\mathrm{Y}$-sperm cells. The sorted sperm cell artificially inseminated into a woman uterus for the desired gender ${ }^{9}$. In spite of the fact that hundreds of healthy children have been born using sperm sorting, it is raises ethical issues, manipulation of human genome, long-term safety against infectious and communicable diseases.

Pre-Implantation Diagnosis (PGD): "In vitro" is a Latin word for "within the glass" 5 . Pre-Implantation Diagnosis (PGD) involves in vitro fertilization of an egg to determine the gender of a baby. The mother's eggs and father's sperm are collected for fertilization in the laboratory. After three days of development, the fertilized eggs are examined for clinical re-implantation into the mother's uterus ${ }^{10}$.

The pre-implantation diagnosis is almost $100 \%$ effective, but the procedure seems invasive, expensive, and controversial ${ }^{11}$. "In some of the fertility canters in Nigeria, PGD is in place and can be assessed, but we advise our patients that it is done in patients with a high index of the possibility of a sex-linked disorder" ${ }^{9-12}$. Suppose the significant risk of gender determination will result a child with a disease or disability ${ }^{13}$. The objection to gender determination we assume that the risk is significantly greater than the risk in normal pregnancy

Ethical Issues: Genetic gender determination could lead to "gender eugenics" and the spread of virulent disease, which could lead to a tragedy of civilization $^{14}$. It is an attempt to create a child as a means to an end. While we acknowledged the above assertion, now there is no evidence of the spread of virulent disease or design babies with human characteristics due to genetic gender determination.

Critics would say that gender determination is akin to "playing God." It is unnatural for a human being to interfere with the natural process of reproduction. We contend that if nature had balanced the genders in a family hood, humankind wouldn't strive for a balance. The human distortions of nature is the human desires for satisfaction and picking a balance for survival ${ }^{15}$.

Gender determination is an ethical response to avert X-linked genetic diseases among children. "Sex detection of fetus before delivery in the first trimester of pregnancy will prevent babies with abnormalities being born" " However, the above assertion negates disability right but we maintain that it is morally right to adhere to the best consequence, for the common good of the society.

Conclusion: A thorough examination of the pros and cons of gender determination, one would say that gender determination be approved to mitigate the effects of the economic recession. However, if it is approved by governments, it does not mean it cannot be regulated to avoid unethical practice among researchers, manipulating of the genome, gender preference or sex discrimination are obnoxious practices that must be regulated by law.

\section{References:}

1. .Lisa M, Sara H. The Great Recession, Families, and the Safety Net. Industrial 
Relations: A Journal of Economy and Societ.y. DECEMBER 19, 2018 available https://irle.berkeley.edu/the-greatrecession-families-and-the-safety-net/

September 2019).

2. What is Economic Recession? Definition, Causes \& Effects.

https://study.com/academy/lesson/what-iseconomic-recession-definition-causeseffects.html (14 September 2019).

3. Andrew C, Erin C, Philip M. The Effects of the Great Recession on Family Structure and Fertility. The Annals of the America Academy of political and Social science. September 25, 2013.

https://doi.org/10.1177/0002716213500643

4. Ademiluka S. Patriarchy and Women Abuse. OTE 2018; 2(31):339-362

5. Osebor I. Decriminalizing Social Sex Selection is a Negation of the Sociological Jurisprudence. Research \& Reviews: Research Journal of Biology, 2018; $6(2)$ : $\quad 1-5$. http://www.rroij.com/open-

access/decriminalizing-social-sex-selection-is-anegation-of-thesociologicaljurisprudence.php?aid=87131 $\quad(14$ September 2019).

6. Julian S. Making Better Babies: Pro And Con. Centre for Human Bioethics2013; 1-3. https://researchmgt.monash.edu/ws/portalfiles/po rtal/252673815/2317892 (14 September 2019).

7. The President's Council on Bioethics: Working Paper 3a. 2012;1-9. https://bioethicsarchive.georgetown.edu/pcbe/ba ckground/sex_selection.html (14 September 2019).

8. Christina R., Veit, M. and Raphael J. Gender Preselection: Facts And Myths The American Fertility Society 1999; 49 (6):2-4. Available from https://www.fertstert.org/article/S00150282(16)59940-3/pdf (14 September 2019).

9. Q \& A On Sex Gender Selection 2018. Available from https://louismedhospital.com.ng/q-a-onsex-gender-selection// (14 September 2019).

10. Richard E. and Kristin H. Gamete Transport and Fertilization, in Human Reproductive Biology. 2014; 1-6. Available from https://www.sciencedirect.com/topics/agricultura 1-and-biological-sciences/sperm-sorting

September 2019).

11. Sparrow R, Gender Eugenics? The Ethics Of PGD For Intersex Conditions. American Journal of Bioethics. 2013, 13(10):29-38. DOI: 10.1080/15265161.2013.828115.

12. World Health Organization Family planning/Contraception. 2018; $\quad 1-3$. https://www.who.int/news-room/fact- $\quad \mathbf{1 1 4}$ September 2019)

13. Michael L. Sperm Sorting Method Could Prevent Girls Being Born. 2019;1-5. https://www.newscientist.com/article/2213377sperm-sorting-method-could-prevent-girls-beingborn-scientists-warn/ (14 September 2019).

14. Michelle L. and Richard R. Justice In The Context Of Family Balancing. Science Technol Human Values, $\quad 2013 ; \quad 1(2): \quad 38$. https://doi.org/10.1177/0162243912469412

15. Matthew L. Reproduction The Ethics Of Using Genetic Engineering For Sex Selection. Journal of medical ethics, 2003 (3)30: 465-71. http:.//dx.doi.org/10.1136/jme.

16. Amir AR, Mohammad H S, Ghasem A, and Jalal I M.Prenatal sex determination in suspicious cases of X-linked recessive diseases by the amelogenin gene Iran J Basic Med Sci. 2014 Feb; 17(2): 134-137

Author Contribution: The 1st author Osebor Ikechukwu Monday conceived the idea, did the literature review and wrote the manuscript. The 2nd author Stephen CC Chukwuma checked and edited the manuscript meticulously.

Conflict of Interest: No Conflict of Interest 